\title{
PREVALENCE OF PSYCHOACTIVE SUBSTANCE USE AMONG STUDENTS OF SECONDARY MEDICAL SCHOOL "THE SISTERS OF MERCY" IN MOSTAR
}

\author{
Monija Bošnjak, Kaja Mandić, Dragan Babić \\ Faculty of Health Studies, University of Mostar, Bosnia and Herzegovina \\ Rad je primljen 17.02.2019. Rad je recenziran 29.02.2019. Rad je prihvaćen 09.03.2019.
}

\begin{abstract}
INTRODUCTION: The onset of tobacco, alcohol and psychoactive substance use is usually associated with adolescence. Young people are the age group most at risk of adopting and developing addictive behavior due to specificity of the formative years, relative inexperience and risk appetite.

OBJECTIVE: The objective of this study is to investigate the use of psychoactive substances in secondary school students in Mostar, and compare the results of prevalence of psychoactive substance use among students of secondary medical school and secondary school for economics.

SUBJECTS AND METHODS: The study was conducted from October 1 through December 31, 2018. A total of 97 students from the secondary medical school and 96 students from the secondary school for economics were surveyed. The ESPAD questionnaire was used as the research instrument.

RESULTS: The most common types of risk behaviors among students from both schools were smoking and consumption of alcoholic beverages. Students with poor academic performance come into contact with cigarette smoking significantly earlier and misuse glue and other solvents significantly more than students with good academic performance $(\mathrm{p}<0,001)$. There was no statistically significant difference between the two groups with respect to consumption of alcoholic beverages and other types of psychoactive substances. There was also no statistically significant difference with respect to sex.

Conclusion: The most common types of risk behaviors among students were smoking and consumption of alcoholic beverages. There was no statistically significant difference in the prevalence of psychoactive substance use between students from the secondary medical school and secondary school for economics.
\end{abstract}

Key words: psychoactive substances, use, students, prevalence

Correspondence: Professor Dragan Babić, $\mathrm{MD}, \mathrm{PhD}$

Email: dragan.babic@fzs.sum.ba 


\section{INTRODUCTION}

The onset of tobacco, alcohol and other psychoactive substances use is often associated with adolescence, and young people are the age group most at risk of adopting and developing addictive behaviors due to specificity of the formative years, relative inexperience and risk appetite (1). As regards to traditional drugs such as alcohol and tobacco, many young people will start using them considering they are socially acceptable behavior (2). Young people whose peers or family have positive expectations from the effects of alcohol, reach out for alcohol more easily and frequently (3). It is a common feature of psychomotor stimulants to cause significant changes in mental functions and behaviors in the form of motor activity stimulation and reduction of fatigue (4). There are different approaches to the definition and classification of psychoactive substances. The aforementioned depends on the perspective of the author and characteristics of the concept under consideration, consequently we can talk about medical, psychological, biological, sociological and many other aspects of defining and classifying of psychoactive substances (5). Psychoactive substance is defined as the substance that acts on the central nervous system and alters not only the psychological but also physical functioning of an individual (6). In addition to the term psychoactive substances, the more familiar term is "drugs" and it is used by the Anti-Drug Abuse Act, where it is defined as a substance of natural or artificial origin, including psychotropic substances provided by the drugs and psychoactive substances list. A common feature of all the above mentioned definitions is that it includes chemical compounds of natural of synthetic origin that change the physical and psychological process of its consumers, and also adversely affect the person and can lead to addiction. Despite numerous definitions by authors and organizations specialized in such issues, there is no generally accepted definition of drugs, in other words, it is not unitary. In addition, there are language problems, the word drug in English stands for medication but when used in a given context it can also stand for illegal substance, and this can lead to confusion during use of certain terms (7).

The second criterion for dividing psychoactive substances is by their effect on the central nervous system. In regards to this we distinguish between psychostimulants, depressants, hallucinogenic substances and cannabinoids. However, similar to the definition and due to a large number of authors who offer different classifications of psychoactive substances, a modification or a systematic representation is required which will make it easier to understand these classifications (8). There are two types of disorders associated with psychoactive substances: abuse and addiction. Abuse is when a person consumes a psychoactive substance but there is no sign of psychic or physical addiction nor there is any violation of social norms (9). Addiction is defined as a distinctive pathological way of psychoactive substance use followed by impairment of physical, social and work functions. Pathological use is characterized by an inability to lower the dose or withdraw from psychoactive substance use, all-day intoxication; use of psychoactive substance on a daily basis for a period of one month and episodes of overdose or intoxication which impair mental functioning. Impaired work functions include loss of friends, family breakdown, unemployment and criminal propensity (10).

Some people (especially young people) are "open" towards the world and the possibilities that it offers, they want to see new things and gain new experiences. Some of them direct their curiosity on adventurous journeys and attractive sports and others experiment with "exciting" drugs. Most of them only temporarily enter the world of drugs and move forward in the pursuit of new life values. For others drugs become indispensable and they become heavy drug users. A certain number of young people are not interested in taking drugs but simply follow their peers and enter the world of addiction (11). This is exactly why it is necessary to work on the change of attitudes towards alcohol consumption, cigarette smoking and use of psychoactive substances as well 
as early detection and treatment of addicts within the family. The problem of the presence of tobacco, alcohol and marijuana should be continuously monitored. Adequate prevention of addiction problems among young people is necessary. In addition to parents, schools and institutions dealing with addiction problems, support should also be available from other institutions to prevent and reduce this problem among young people (12).

The objective of this study is to examine and compare the prevalence of psychoactive substance use among students of two secondary schools in Mostar, Secondary Medical School "Sisters of Mercy" and Secondary School for Economics.

\section{SUBJECTS AND METHODS}

\section{Study location and subjects}

The study was conducted from 1 October to 31 December 2018 at the Secondary Medical School "Sisters of Mercy" and Secondary School for Sconomics in Mostar. The study included 200 subjects. The test group included 100 students from the $3^{\text {rd }}$ and $4^{\text {th }}$ grade of the Secondary Medical School "Sisters of Mercy" and the control group included 100 students from the 3rd and 4th grade of the Secondary School for Economics.

\section{Methods}

This was a cross-sectional study and data were collected by means of anonymous and voluntary surveys. The research instrument was a modified questionnaire of the European School Survey Project on Alcohol and Other Drugs (ESPAD) (13). Taking into consideration that the number of students in relation to school performance was not equal in proportion, in order for the two groups to be comparable, students with sufficient and good school achievement made up the lower achievement group while students with very good and excellent school achievement made up the higher achievement group.

\section{Statistical evaluation of data}

The data was statistically processed by means of descriptive statistics methods and are presented in tabular and pictorial form. Chi-square test and Fisher's exact test were used to test the differences between groups. The probability value of $p<0.05$ was taken as statistically significant in all of the test. The SPSS for Windows software (version 15.0, SPSS Inc., Chicago, Illinois, USA) was used for statistical analyses of data.

\section{RESULTS}

Out of the total number of 200 surveyed students, seven of them did not complete the questionnaire so in the end we statistically analyzed data from 193 students. The study included students of both genders from 17 to 19 years old, 22 (22.6\%) male students and 75 (77.4\%) female students from the Secondary Medical School and 31 (32.3\%) male students and 65 (67.7\%) female students from the Secondary School for Economics (Table 1).

Table 1 - Sociodemographic characteristics of respondents

\begin{tabular}{|c|c|c|c|}
\hline Variable & $\begin{array}{l}\text { Medical } \\
\text { school } \\
(n=97)\end{array}$ & $\begin{array}{c}\text { School for } \\
\text { economics } \\
(n=96)\end{array}$ & $\mathrm{p}$ \\
\hline Age & $17.6 \pm 0.52$ & $17.3 \pm 0.97$ & 0.463 \\
\hline Gender & & & \\
\hline Male & $22(22.6)$ & $31(32.3)$ & 0.099 \\
\hline Female & $75(74.4)$ & $65(67.7)$ & \\
\hline $\begin{array}{l}\text { School achievement } \\
\text { in the previous scho- } \\
\text { ol year }\end{array}$ & & & \\
\hline Lower achievement & $33(34.0)$ & $22(22.9)$ & 0.087 \\
\hline Higher achievement & $64(66.0)$ & $74(77.1)$ & \\
\hline
\end{tabular}

A total of $43.5 \%$ of students reported of never having contact with cigarette smoking while $14.5 \%$ of them stated that their first contact was before the age of 12 ( $\chi 2$ test $=38.358$; d.f. 3 ; $\mathrm{p}<0.001)$. Students with lower school achievement have come into contact with cigarette smoking significantly earlier than their peers with higher school achievement $(\chi 2$ test $=17.706$; d.f. 3 ; $\mathrm{p}<0.001)$ (Table 2). 


\begin{tabular}{|c|c|c|c|c|c|c|}
\hline \multirow{2}{*}{\multicolumn{2}{|c|}{$\begin{array}{l}\text { Parameter } \\
\text { N (\%) }\end{array}$}} & Never & $\begin{array}{c}\leq 12 \text { years } \\
\text { old }\end{array}$ & $\begin{array}{c}\text { 13-15 years } \\
\text { old }\end{array}$ & $\begin{array}{c}\geq 16 \text { years } \\
\text { old }\end{array}$ & \multirow[t]{2}{*}{$\mathrm{p}$} \\
\hline & & $\mathrm{N}(\%)$ & $\mathrm{N}(\%)$ & $\mathrm{N}(\%)$ & & \\
\hline \multirow[t]{2}{*}{ Secondary school } & Medical school & $38(39.1)$ & $15(15.4)$ & $31(31.9)$ & $13(13.6)$ & \multirow[t]{2}{*}{0.129} \\
\hline & School for economics & $45(46.9)$ & $13(13.5)$ & $18(18.8)$ & $20(20.9)$ & \\
\hline \multirow[t]{2}{*}{ Gender } & Male & $24(45.3)$ & $9(16.9)$ & $10(18.9)$ & $10(18.9)$ & \multirow[t]{2}{*}{0.624} \\
\hline & Female & $59(42.1)$ & $19(13.6)$ & $39(27.8)$ & $23(16.5)$ & \\
\hline \multirow[t]{2}{*}{ School achievement } & Lower & $13(23.6)$ & $14(25.4)$ & $20(36.5)$ & $8(14.5)$ & \multirow[t]{2}{*}{$<0.001$} \\
\hline & Higher & $70(50.7)$ & $14(10.1)$ & $29(21.1)$ & $25(18.1)$ & \\
\hline
\end{tabular}

Table 2 - Distribution of students according to age of first contact with cigarette smoking in relation to observed parameters

A total of $73.5 \%$ of students never became active smokers i.e. they never smoked at least one cigarette a day $(\chi 2$-test $=246.192$ d.f. $3 ; \mathrm{p}<0.001)$ (Picture 1$)$.

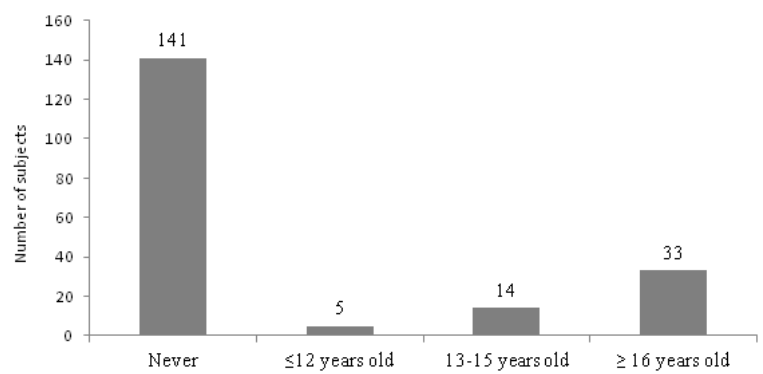

Picture 1 - Distribution of students according to age at which they started smoking at least one cigarette a day

A total of $51.3 \%$ of students have never been drunk or intoxicated with alcohol while $3.65 \%$ of them were heavily intoxicated by alcohol 6 to 9 times ( $\chi 2$-test $=212.375$ d.f. 5; $\mathrm{p}<0.001$ ) (Picture 2).

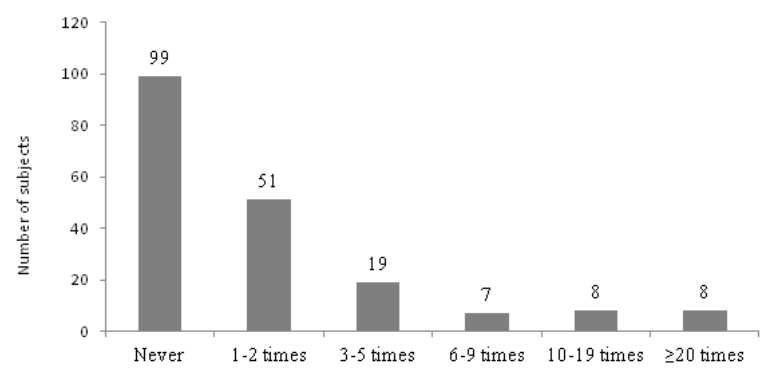

Picture 2 - Distribution of students according to the number of alcohol intoxications

The highest percentage of students (83.9\%) never took sedatives prescribed by the doctor, while the lowest percentage (4.6\%) stated they took sedatives for three or more weeks $(\chi 2$-test $=223.72$ d.f. 2; $\mathrm{p}<0.001$ ) (Picture 3).

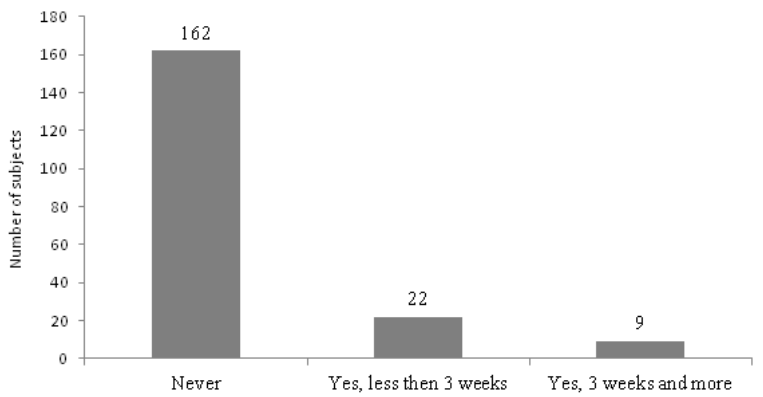

Picture 3 - Distribution of students according to prevalence of sedative use

The highest percentage of students (85.4\%) never used cannabis while the smallest percentage (3.1\%) used it 3 to 5 times ( $\chi 2$-test $=377.052$ d.f. $3 ; \mathrm{p}<0.001$ ) (Picture 4).

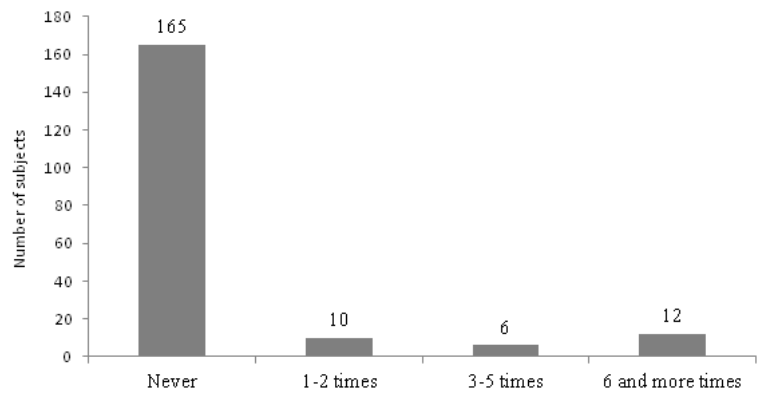

Picture 4 - Distribution of students according to the frequency of cannabis use

The highest percentage of students (85.4\%) haven't used cannabis in the past 12 months while $6.2 \%$ of them used it once or twice ( $\chi 2$-test $=414.125$ d.f. 3; $\mathrm{p}<0.001$ ) (Picture 5) 


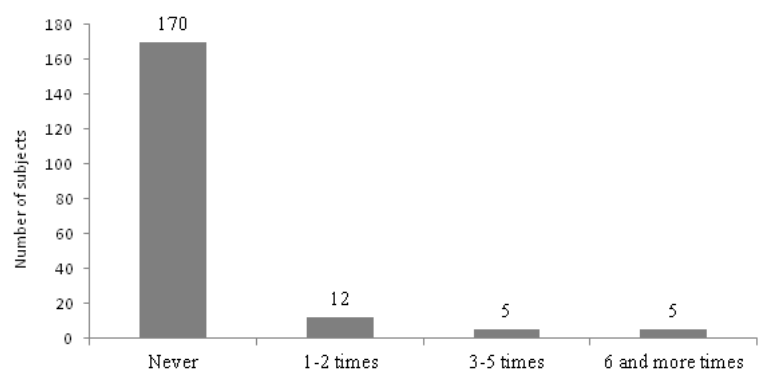

Picture 5 - Distribution of students according to the frequency of cannabis use in the past 12 months

The highest percentage of students (85.4\%) haven't used cannabis in past 30 days while $4.6 \%$ of them used it once or twice ( $\chi 2$-test $=414.749$ d.f. 3; $\mathrm{p}<0.001$ ) (Picture 6).

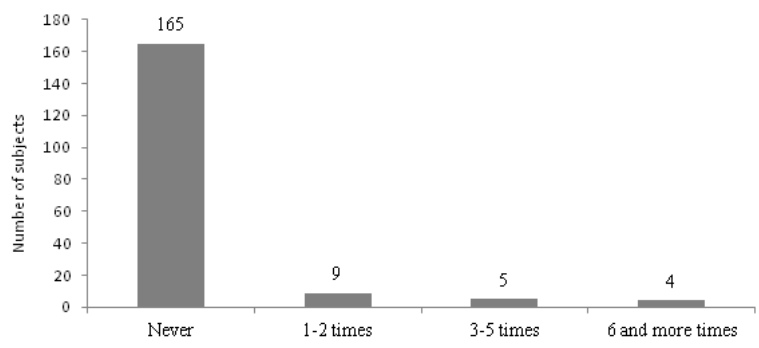

Picture 6- Distribution of students according to the frequency of cannabis use in the past 30 days

The highest percentage of students $(88.6 \%)$ have never sniffed glue or other solvents $(\chi 2$-test $=414.749$ d.f. 3; $\mathrm{p}<0.001$ ) (Picture 7).

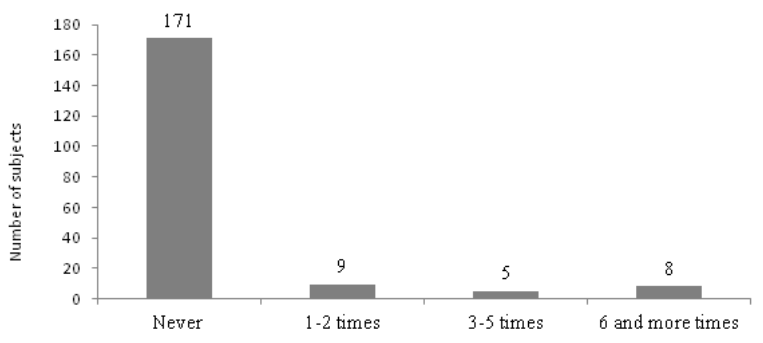

Picture 7 - Distribution of students according to the frequency of sniffing glue or other solvents

The highest percentage of students (80.3\%) have never taken any type of psychoactive substance ( $\chi 2$ test $=444.250$ d.f. $5 ; \mathrm{p}<0.001)$ while the highest percentage of those who did, do not remember the reason for taking psychoactive substances (Picture $8)$.

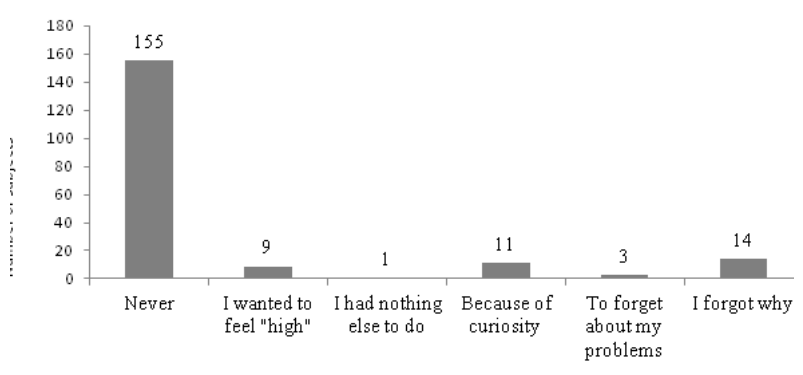

Picture 8 - Distribution of students according to reasons for psychoactive substance use

A significantly higher number of students with lower school achievement stated that they forgotten the reasons for psychoactive substance use $(\chi 2$ test $=328.734$; d.f. 5; $\mathrm{p}<0.001)$ (Table 3).

Table 3 - Distribution of students according to reasons for psychoactive substance use

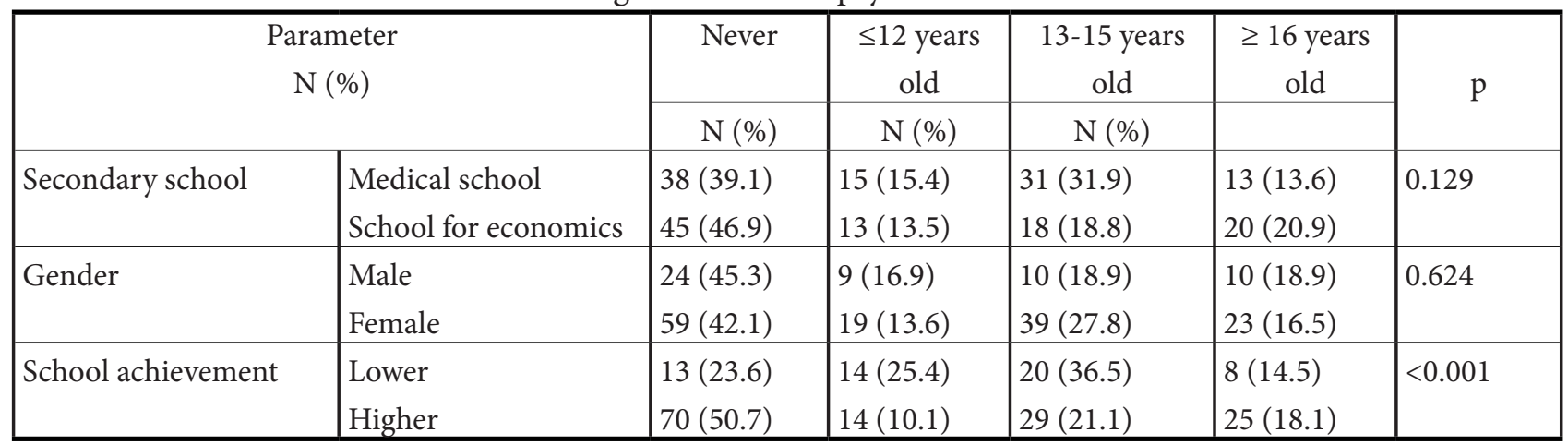




\section{DISCUSSION}

The conducted study points to significant facts regarding the habits and behaviors of secondary school students in Mostar and their use of psychoactive substances. More than half of the students have never come into contact with cigarette smoking in their lives while more than one quarter of them smoke at least one cigarette a day and can be categorized as active smokers. In recent years, numerous population studies have confirmed that smoking is the largest single risk factor for health in all age groups of the population. According to the results of the Adult Health Survey of the Federation of Bosnia and Herzegovina (FB\&H) conducted by the Institute for Public Health of the Federation of Bosnia and Herzegovina in 2012, 44.1\% of subjects smoked, $56.3 \%$ of them were men and $31.6 \%$ were women. According to the results of the same study, more than half of the subjects (54.1\%) are exposed to passive smoking, in whom less than half of the subjects (44.4\%) reported they were exposed to tobacco smoke from other smokers at work, and over half of the subjects (52.7\%) reported they were exposed to tobacco smoke from other smokers in public places (14). According to the results of the Global Youth Tobacco Survey (GYTS) of students aged 1315 from 2013, 12.7\% of students confirmed cigarette smoking on a daily basis, of which $15.5 \%$ were boys and $9.7 \%$ were girls (15).

These results are to some extent comparable to result from the ESPAD survey on smoking, alcohol and drug consumption among students conducted in 2015. In Croatia, 39.9\% of students have never smoked while $62 \%$ of them have had this experience. With $33 \%$ of current smokers, Croatia is at the very top among 48 countries participating in the research, together with Italy, Romania and Bulgaria (16).

The onset of cigarette smoking is associated with the desire of young people to express adult like behaviors and draw closer to their role models who smoke. They are also influenced by common features associated to young people, school and the wider environment (17). However, their peers, parents and older brothers and sisters still have the greatest influence. Early experimenting, peer pressure, lack of social support and vague parental attitudes contribute to early onset of cigarette smoking (18). The earlier the person starts to smoke, the greater are the chances for more intensive and prolonged smoking in adulthood (19). The study did not show statistically significant differences in the prevalence of psychoactive substances use among the subjects from the two secondary schools. Similar results are reported by Soča and Babić in their study on the prevalence of psychoactive substances use among students from the Secondary School for Traffic and Secondary Medical School "The Sisters of Mercy" in Mostar (20).

More than half of the students (51\%) say that they have never been drunk or intoxicated with alcohol while the rest of them confirm they were affected by it. There was no difference in the frequency of alcohol consumption among students according to their gender. According to the results the study conducted by the Institute for youth development, young people in the Federation of Bosnia and Herzegovina consume less alcohol than their peers from other countries of the Europe Union (EU). More than $42 \%$ of men and $25 \%$ of women between the ages of 15 and 24 have drank alcoholic beverages one or more times in the last 30 days. Although these results may seem favorable when compared to those from the EU, the problem of alcohol consumption among the youth of the FB\&H exists because 33\% of young people drink alcoholic beverages. Young men represent a higher risk group when it comes to the frequency of alcohol consumption, $6 \%$ of them drank alcohol more than 10 times in the last month, 9\% of them drank alcohol 4 to 6 times and 15\% 2 to 3 times (21).

The highest percentage of students (83.9\%) never took sedatives while the rest of the data shows that $11.4 \%$ of them took sedatives for a period of three or more weeks. With respect to inhalation of glue and other solvents, $12 \%$ of students confirmed the same, provided that the majority of them sniffed glue and other solvents only a few times. In recent years, in Bosnia and Herzegovina, especially among young people, there has been an increasing use or 
misuse of the so called legal substitutes for drugs, such examples are narcotic drugs (Tramadol), antiparkinsonics (biperidin), sedatives (benzodiazepines), and some adhesives (Sintelan et al.). All of the mentioned substances can be purchased legally by young people because unfortunately there is no proper control system. Young people who use two or more psychoactive substances have more problems with the authorities, have aggressive behavior, and are more prone to engage in risky sexual behavior and often skip classes. A trend of mixing alcohol and sleeping pills is on the rise among young people (22). The highest percentages of sedative consumption in the EU countries are in Poland (15\%) and Monaco (14\%) (23).

The results show a significant percentage of students who reported of never taking any psychoactive substances. The results of the study conducted by the Institute for Public Health of the Federation of Bosnia and Herzegovina show that young people do not take narcotic drugs ( $87 \%$ in rural areas and $94 \%$ in suburban areas) (21). The presented data on the use of psychoactive substances should be viewed with caution because the percentage of young people how consume narcotic drugs is much higher. A research conducted by Jakešević and Martinac among secondary school students in Jajce reports that 33\% of them consumed cannabis (24). For instance, some states have legalized the use of cannabis for medical purposes in diseases stipulated by the regulations. Authors and associates state that because of medical benefits of cannabis it is necessary to determine in the scientific benefits of cannabis in the countries' legalizations while taking into account any misuse of cannabis for medical purposes (25).

The phenomena of psychoactive substances addiction is a global problem and raises many questions. Albajtez and Babić state that in today's globalized world, the consumer society has become an inexhaustible resource in the study of consumerism and shoppingholism. The modern man feverishly bows to the trend of uncontrollable spending (26). On the other hand, Babić and associates state that in recent decades, scientists focus their attention on addictions without drugs that is on addictions without out use of psychoactive substances. In the last decades, we are confronted with the growing problem of Internet addiction, gambling addiction that are for the first time categorized in the DSM-V due to addiction disorders of uncontrolled shopping, food carvings, sex addiction, dieting, sports, work and many more, and these are mostly real addictions and not just a way of life (27).

\section{CONCLUSION}

The most common risk behaviors among students are cigarette smoking and alcohol consumption. Lower school achievement proved to be a significant predictor of risk behavior in secondary school students. Students with lower school achievement come into contact with cigarette smoking significantly earlier and abuse glue and other solvents significantly more than students with higher school achievement. There were no statistically significant differences between male and female students regarding the prevalence of psychoactive substances use among students of the Secondary Medical School "The Sisters of Mercy" and Secondary School for Economics in Mostar.

\section{LITERATURE}

1. Bašić J, Ferić M. Children and young people at risk - risk behaviours In: Bašić J, Koller-Trbović N, Uzelac S. (Eds.) Behavioral disorders and risk behaviors: approaches and conceptual definitions. Zagreb: Faculty of Education and Rehabilitation Sciences University of Zagreb, 2004. p. 57-71.

2. Bezinović P. Malatestinić Đ. Perceived Exposure to substance use and risk taking beahvior in early adolescence: Cross-sectional study. Croatian Med Journal. 2009;50:157-64.

3. Babić $\mathrm{D}$, and associates. Psychoactive substances: mental disorders caused by psychoactive substances use. Mostar: University of Mostar; 2016.

4. Dabo J, Malatestinić Đ, Janković S, Bolf Malović M, Kosanović V. Protection of reproductive health of young people - models of prevention. Medicina Fluminensis. 2008;44:1-74. 
5. Birckmayer JD, Holder HD, Yacoubian GS, Friend KB. A general causal model to guide alcohol, tobacco, and illicit drug prevention: Assessing the research evidence. Journal of Drug Education. 2004;34:121-53.

6. Cleveland MJ, Feinberg ME, Bontempo DE, Greenberg MT. The role of risk and protective factors in substance use across adolescence. Journal of Adolescent Health. 2008;43:157-64.

7. Brlas S. Dictionary of addiciton. Virovitica: Department of Public Health of the Virovitica-Podravina County, 2011.

8. Boras I. Growing problems of of intoxication with new psychoactive substances. Zagreb: MEF; 2005.

9. Klarić D. Drugs, an (un)solvable problem. Zagreb: Dvotočka; 2007.

10. Kuzman M. Addcitive behaviours of students in Croatia and Europe. Zagreb: Hrvatski zavod za javno zdravstvo, 2003;173-184.

11. Sakoman S. The role of family in the development of addictive behaviour. Medicus. 2009;18:193-204.

12. Ferić-Šlehan M Risk and protective factors in the family environment: differences in assessment of young people and their parents. Croatian review of rehabilitation research. 2008;44:15-26.

13. The European School Survey Project on Alcohol and Other Drugs ESPAD [Internet] available at: https://www.hzjz.hr/wpcontent /uploads/2013/11/HR_ESPAD _2015.pdf (accessed on February 24 2019).

14. Study on the state of health of adult population in the Federation of $\mathrm{BiH}$ in 2012, The Federal Ministry of Health, Institute for Public Health of the Federation of Bosnia and Herzegovina, 2014.

15. The Global Youth Tobacco Survey (GYTS) 2013, The Federal Ministry of Health, Institute for Public Health of the Federation of Bosnia and Herzegovina, 2014.

16. The Global Youth Tobacco Survey (GYTS), Croatian Institute for Public Health, 2015. [Internet] available at : www.hzjz.hr. (accessed on February 24 2019).
17. Ivandić-Zimić J. Risk factors for drug addiction with an emphasis on factors in the family environment. Criminology and Social Integration 2011;19:65-80.

18. Raboteg-Šarić Z, Sakoman S, Brajša-Žganec A. Parenting styles, free time and adolescent risk behaviors. Journal of Social Issues. 2002;11:23963.

19. Greblo M, Šegregur J. The habit of smoking, drinking alcohol and substance abuse in adolescents. Croatian Journal for Public Health. 2011; 6:23-17.

20. Soča M, Babić D. The prevalence of psychoactive substances in secondary school youth. The Health Bulletin 2015;1:44-50.

21. Institute for Youth Development .Towards a Youth Policy in FBiH - Survey on the Position and Needs of Youth in the Federation of Bosnia and Herzegovina 2013. [Internet Available at: mladi.org/v2/bs/component/.../37-podrska-mladima-u-fbih? (accessed on February 25 2019).

22. Study on the state of health of the population in the Federation of Bosnia and Herzegovina 2012, The Federal Ministry of Health, Institute for Public Health of the Federation of Bosnia and Herzegovina, 2014.

23. WHO Psychoactive substances. [Internet] Available at: http://www.who.int/substance_ abuse/terminology/psychoactive_substances/ en/. (accessed on February 26 2019).

24. Jakešević A, Martinac M. The prevalence of marijuana and hashish abuse among secodary school students in Jajce. The Health Bulletin. 2015;1:25-36.

25. Batori M, Žerovnik A, Barać K, Babić D. The positive health benefits of cannabis. The Health Bulletin. 2018;2:50-59.

26. Ajtlbez L, Babić D. Shoppingholizam - addiction of the modern age. The Health Bulletin. 2016;2: 72-82.

27. Babić R, Babić D, Martinac M, Pavlović M, Vasilj I, Miljko i sur. Addictions without drugs: Contemporary Addictions or Way of Life? Psychiatria Danubina, 2018;30:371-9. 


\title{
POJAVNOST UPORABE PSIHOAKTIVNIH TVARI UČENIKA SREDNJE MEDICINSKE ŠKOLE SESTARA MILOSRDNICA MOSTAR
}

\author{
Monija Bošnjak, Kaja Mandić, Dragan Babić \\ Fakultet zdravstvenih studija Sveučilišta u Mostaru, Mostar, Bosna i Hercegovina
}

\section{SAŽETAK}

UVOD: Početak uporabe duhana, alkoholnih pića i psihoaktivnih tvari obično se vezuje za adolescenciju, a mladi su, zbog specifičnosti razdoblja odrastanja, relativnog neiskustva, te određene sklonosti rizicima, najugroženija populacijska skupina za usvajanje i razvoj ovisničkoga ponašanja.

CILJ RADA: Ispitati i usporediti pojavnost uporabe psihoaktivnih tvari u učenika Srednje medicinske škole Sestara milosrdnica Mostar i Srednje ekonomske škole u Mostaru.

ISPITANICI I METODE: Istraživanje se provodilo od 1. listopada do 31. prosinca 2018. godine. Ukupno je anketirano 97 učenika medicinske i 96 učenika ekonomske škole. Za potrebe istraživanja korišten je ESPAD upitnik.

REZULTATI: Najzastupljenija rizična ponašanja među učenicima obje škole su pušenje i pijenje alkoholnih pića. Učenici/ ce lošijeg školskog uspjeha statistički značajno ranije dolaze u doticaj s pušenjem cigareta te značajno više zloporabljuju ljepila i druga otapala u odnosu na učenike/ce boljeg školskog uspjeha $(\mathrm{p}<0,001)$. U odnosu na pijenje alkoholnih pića i druge vrste psihoaktivnih tvari među ispitivanim skupinama nije bilo statistički značajne razlike. U ispitivanom uzorku nema statistističi značajne razlike u odnosu na spol.

ZAKLJUČAK: Najzastupljenija rizična ponašanja među učenicima su pušenje i pijenje alkoholnih pića. Ne postoji statistički značajna razlika u pojavnosti uporabe psihoaktivnih tvari između učenika/ica Srednje medicinske i ekonomske škole.

Ključne riječi: psihoaktivne tvari, uporaba, učenici, pojavnost.

Osoba za razmjenu informacija:

Prof. dr. sc. Dragan Babić

E-adresa: dragan.babic@fzs.sum.ba 